\section{Exploratory Factor Analysis of the Chilean Deafness Attitude Scale.}

\author{
Natalia Belmar, ${ }^{1}$ Isabel Quappe, ${ }^{1}$ Luis Luengo $^{1}$ \& \\ Valeria Campos. ${ }^{1}$
}

Abstract: Negative attitudes mean a barrier for People with Disability (PwD), but attitudes towards Deaf people are structurally different from the rest of the PwD. The aim of this study is to evaluate the factorial structure and internal reliability of the Attitudes towards Deafness Scale (ADS) applied in health professionals from Concepcion, Chile. The ADS was translated to Spanish and back-translated to English, then reviewed by public health experts, and a pilot application was carried out to 15 health professional to make final modifications. The Chilean ADS version was applied to 182 health professional from primary care centers and academics working in health schools. Reliability analysis with estimation of the Cronbach's alpha coefficient, and exploratory factor analysis were made. The data presented adequate values to perform exploratory factor analysis (KMO $=0.73$; Bartlett's sphericity test $p<0.00001)$. A maximum likelihood extraction method and a Quartimax rotation method with Kaiser standardization were used for a fourfactor model, in which 11 items presented loads of less than 0.5 , so the final model was left with 11 items. A Cronbach's alpha coefficient of 0.70 was determined in the final model, with an alpha of 0.77 for the first factor, 0.55 for the second, 0.77 for the third, and $\mathbf{0 . 6 1}$ for the fourth. The exploratory factor analysis suggested a four-dimensional structure for ADS Chilean version. The four subscales and the scale in general presented an adequate Cronbach's alpha, suggesting acceptable internal consistency

Keywords: Attitudes, Deafness, Scale, Chile.

\section{INTRODUCTION}

There are currently 360 million people with hearing disabilities; in Chile, this represents $8.2 \%$ of the adult population with disabilities (WHO, 2015; Ministerio de Desarrollo Social, 2015). This disability is defined as a reduction or loss in the ability to perceive or process sounds (WHO, 2015, Shearer et al., 2018). Generally, people who were born deaf or lost their hearing at an early age are not assumed to be part of a group associated with disability, but as part of a linguistic minority. They participate in the Deaf community, which corresponds to a world with its own language and culture, customs, and values arising from its auditory condition. They use sign language as a means of communication of choice to interact and they call themselves "Deaf" with a capital "D". Within this area, sign language $(\mathrm{SL})$ is the most significant cultural element of the Deaf community. SL presents a linguistic organization different from that of the spoken languages. SL is not universal, but varies according to the country or geographic region (Campos, 2016; Padden \& Humphries, 2005; Humphries \& Humphries 2010; Ladd P, 2003; De Meulder, 2015), and is recognized in more than 30 countries (De Meulder, 2015).

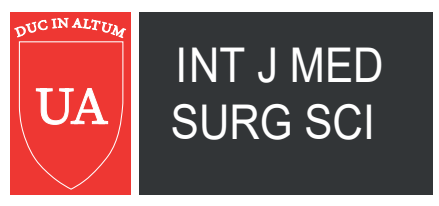

Affiliations: ${ }^{1}$ Facultad de Odontología,

Universidad de Concepción, Chile.

Corresponding author: Valeria Campos Cannobbio. Beltrán Mathieu 7, Concepción. Phone $+\mathbf{5 6 9 7 7 5 7 5 6 5 5}$.

E-mail:valeriacamposcannobbio@gmail.com.

Receipt:

$10 / 02 / 2018$

Revised:

$10 / 24 / 2018$

Acceptance:

$10 / 30 / 2018$

Online:

$11 / 23 / 2018$
Conflict of interests: None.

Ethics approval: This study was approved by the Research and Bioethics Committee of the University of Concepción School of Dentistry (C.I.Y.B. $\left.N^{\circ} 012 / 18\right)$.

Funding: None.

Authors' contributions: All authors carried out the entire study

Acknowledgements: None.

doi: $\underline{10.32457 / \mathrm{ijmss} .2018 .020 .}$. 
Deaf people have particularities in the way they relate to the rest of society, especially due to differences in aspects of communication (Kuenburg et al., 2016; Merten et al., 2015; Emond et al., 2015). This represents a great barrier in healthcare centers, affecting the quality of healthcare delivered to these individuals, and therefore harming their health outcomes. On the other hand, health professionals have limited competencies to meet the specific needs of this population, which results in user dissatisfaction, barriers to access at different levels of prevention, and communication problems (Kuenburg et al., 2016; Merten et al., 2015; Emond et al., 2015).

Negative attitudes mean a barrier to the inclusion and personal development of People with Disabilities (PwD), with perceptions of abandonment and apathy on the part of society, with a consequent isolation, lack of self-esteem, and depression (Erting et al., 1994). These attitudes have also been evaluated in health professionals, where negative attitudes have been described, hindering the attention given to these people (Eagly \& Chaiken, 2007; Patka et al., 2013). Specifically, Meadow-Orlans and Erting (Hindley \& Kitson, 2000) described negative attitudes towards people with hearing disabilities. Hindley and Kitson (2000) described attitudes in which deafness generates pity and efforts to make deaf children as close as possible to hearing children.

Several instruments have been reported to measure attitudes toward PwD (Power et al., 2010, Stevens et al., 2013; Palad et al., 2016). However, according to Kiger (1997), attitudes towards Deaf people are structurally different from the rest of the PwD community. In view of this, in 2004, an instrument was created and validated to specifically measure the attitude of health professionals towards Deafness, i.e. the Deafness Attitude Scale (Cooper et al., 2004).

The aim of this study was to evaluate the factorial structure and internal reliability of the Attitudes towards Deafness Scale (ADS) applied to health professionals from Concepcion, Chile.

\section{MATERIALS AND METHODS}

The target population was comprised of 182 health professionals from the province of Concepción. The sample was obtained from: a) academics from the University of Concepción (UdeC); and b) personnel from different public primary healthcare centers (PHC). We excluded primary healthcare staff who do not perform clinical duties, and foreign professionals or native speakers of a language other than Spanish.

There is no exact number for validation studies of scales, but between 2 to 20 participants per item are recommended, with a minimum of 100-250 participants (Beaton et al., 2000). The Attitude Towards Deafness Scale is composed of 22 items, so the estimated sample size ranges from 44-440.

The ADS was developed in England by Cooper, Rose \& Mason, and is composed of 22 items scored using a Likert scale of 1 to 6 points (Cooper et al., 2004). After the instrument is applied, the answers are rated 1-6 or 6-1, depending on whether the statement reflects a positive or negative attitude. A score of 6 indicates the most positive response to the affirmation and a score of 1 indicates the most negative response. This instrument has shown adequate psychometric properties with a Cronbach's alpha of 0.71 . The application of the instrument takes around 10 minutes.

The translation and adaptation process was carried out according to Beaton (2000) and Sousa \& Rojjanasrirat (2011). Two native Spanish-speaking professionals competent in English translated the English version into Spanish independently. The versions were coded as TE1 (translation performed by a dentist) and TE2 (translation performed by a professional translator without knowledge in the health area). Then, consensus was reached between both versions, with the support of a third bilingual professional (MPH/ $\mathrm{PhD}$ psychologist). The translated version was backtranslated by the same method, generating TI1 and TI2, respectively. Subsequently, four Chilean public health experts reviewed the process for obtaining a preliminary version of the Spanish version of the ADS. Throughout the process, feedback was maintained with the lead author who developed the scale. A pilot was carried out with 15 professionals from the University of Concepción School of Dentistry. The difficulties and problems of understanding 
the scale were evaluated, and small modifications were made. The last evaluation was carried out by a group of experts, and the main author who developed the scale was consulted.

The data collection was carried out in the same PHC centers and in the health schools of the University of Concepción. There was no monetary compensation associated with participation. The professionals were selected based on accessibility. Each participant was informed of the study aim and their voluntary participation was obtained through signed informed consent. Prior to receiving informed consent from the participant, the survey was conducted anonymously, and was delivered to a mailbox by the participant, ensuring confidentiality. For the data collection in PHC, the authorization of each Director of the PHC centers was requested. Once authorized, between one and two visits were made to each health center, previously agreed with its director. For data collection at the University of Concepción, authorization was requested from each Dean of the schools. Once authorized, between one and two visits were made to each school, previously agreed with the Dean.

Data were tabulated in an Excel spreadsheet by a researcher. The analysis of the data consisted of: (i) characterization of the sample, (ii) a reliability analysis with estimation of the Cronbach's alpha coefficient and the calculation of correlations between elements and item correlations with the total score; (iii) an exploratory factor analysis, including measures of adequacy (KMO and Bartlett's sphericity test), extraction methods (principal components, maximum likelihood and main axes), and rotation (Varimax and Promax). SPSS v.23 for Windows (IBM, USA) was used for the analysis.

\section{RESULTS}

The sample consisted of 182 health professionals; the sociodemographic characterization is shown in Table 1. A Cronbach's alpha coefficient of 0.67 was determined (Table 2).

The data presented adequate values to perform exploratory factor analysis $(\mathrm{KMO}=0.73$; Bartlett's sphericity test $p<0.00001)$. Through the criterion of eigenvalues, eight dimensions were suggested (Table 3). The criterion of the sedimentation graph suggested three dimensions (Figure 1).

Different extraction and rotation methods were tested. Finally, a maximum likelihood extraction method and a Quartimax rotation method with Kaiser standardization were chosen. For this, we worked with a four-factor model according to self-explained variance criteria, sedimentation graph and eigenvalues. (Table 4)

In this model, 11 items presented loads of less than 0.5 , so the final model was left with 11 items. A Cronbach's alpha coefficient of 0.70 was determined in the final model, with an alpha of 0.77 for the first factor, 0.55 for the second, 0.77 for the third, and 0.61 for the fourth.

\section{TABLE 1. Sample chracterization.}

Male (\%)

Female (\%)

74.7

Age (years, mean, min-max)

$39(23-79)$

Years on service (mean, min-

$\max$ )

Years on service for healthcare

$10.5(1-50)$

staff (mean, min-max)

Years on service for faculty staff 11.5 (1-47)

(mean, min-max)

DDS (\%)

35.2

Paramedic (\%)

26.4

Nurse (\%)

10.4

MD (\%)

9.3

Midwife (\%)

6

Nutritionist (\%)

3.8

Physical therapist (\%)

3.3

PsyD (\%)

3.3

PharmD (\%)

1.1

Speech therapist (\%)

0.5

They have training on Deafness

12.6

(\%)

They delivered healthcare to

82.4 
TABLE 2. Internal consistency of ADS (items in Spanish).

\begin{tabular}{|c|c|c|c|c|}
\hline Items & $\begin{array}{l}\text { Scale mean } \\
\text { if item } \\
\text { deleted }\end{array}$ & $\begin{array}{l}\text { Scale vari- } \\
\text { ance if item } \\
\text { deleted }\end{array}$ & $\begin{array}{l}\text { Corrected } \\
\text { item-total } \\
\text { correlation }\end{array}$ & $\begin{array}{c}\text { Cronbach's } \\
\text { alpha if item } \\
\text { deleted }\end{array}$ \\
\hline $\begin{array}{l}\text { Las personas sordas deben aprender a hablar más que } \\
\text { aprender lengua de señas }\end{array}$ & 78.4867 & 129.549 & .599 & .624 \\
\hline $\begin{array}{l}\text { Los niños sordos deben aprender a hablar para comuni- } \\
\text { carse con sus padres oyentes. }\end{array}$ & 79.4913 & 128.009 & .491 & .630 \\
\hline Las personas sordas son discapacitadas & 79.1899 & 130.507 & .459 & .635 \\
\hline $\begin{array}{l}\text { Las parejas de personas sordas deberían recibir conse- } \\
\text { jería genética para evitar tener hijos sordos. }\end{array}$ & 80.4759 & 137.186 & .410 & .646 \\
\hline $\begin{array}{l}\text { El tener un colega sordo podría causar problemas en el } \\
\text { lugar de trabajo. }\end{array}$ & 78.9021 & 133.993 & .362 & .647 \\
\hline $\begin{array}{l}\text { Hijos oyentes de padres sordos están en riesgo de caren- } \\
\text { cia emocional. }\end{array}$ & 78.1262 & 139.665 & .358 & .651 \\
\hline $\begin{array}{l}\text { Los colegios para sordos y asociaciones de sordos crean } \\
\text { guetos de sordos. }\end{array}$ & 79.3188 & 137.384 & .357 & .650 \\
\hline Debe ser difícil tener un amigo sordo. & 78.5654 & 139.085 & .334 & .653 \\
\hline $\begin{array}{l}\text { Capacitar a más profesionales de la salud mental para } \\
\text { trabajar con clientes sordos sería una pérdida de tiempo. }\end{array}$ & 78.7633 & 139.681 & .332 & .653 \\
\hline $\begin{array}{l}\text { Las personas sordas son fisiológicamente discapacita- } \\
\text { das. }\end{array}$ & 77.8847 & 140.224 & .313 & .655 \\
\hline Me gustaría tener más colegas sordos. & 78.5518 & 141.256 & .255 & .660 \\
\hline $\begin{array}{l}\text { Me gustaría ver más personas sordas en los clubes/so- } \\
\text { ciedades a las que asisto. }\end{array}$ & 80.1169 & 142.256 & .254 & .661 \\
\hline $\begin{array}{l}\text { A todas las personas sordas se le debería ofrecer cirugía } \\
\text { correctiva. }\end{array}$ & 80.4093 & 141.732 & .245 & .661 \\
\hline $\begin{array}{l}\text { Se debería realizar más investigación para encontrar la } \\
\text { cura a la sordera. }\end{array}$ & 81.0081 & 144.133 & .221 & .664 \\
\hline Las personas sordas son conductores seguros. & 80.6053 & 145.124 & .181 & .668 \\
\hline $\begin{array}{l}\text { Las personas sordas deben recibir automáticamente } \\
\text { ayuda en su entorno familiar. }\end{array}$ & 81.0710 & 146.773 & .166 & .669 \\
\hline $\begin{array}{l}\text { Las personas sordas no deberían ser consideradas como } \\
\text { "discapacitadas". }\end{array}$ & 79.4600 & 144.064 & .163 & .670 \\
\hline Me gustaría tener más amigos sordos. & 79.6256 & 150.562 & .031 & .681 \\
\hline $\begin{array}{l}\text { Los niños sordos deberían ser educados en lengua de } \\
\text { señas }\end{array}$ & 77.7963 & 156.471 & -.133 & .690 \\
\hline $\begin{array}{l}\text { Debe haber disponibilidad de intérpretes de lengua de } \\
\text { señas para las personas sordas en el trabajo. }\end{array}$ & 78.0097 & 157.307 & -.155 & .693 \\
\hline Las personas sordas tienen su propia cultura. & 80.6052 & 166.680 & -.382 & .718 \\
\hline
\end{tabular}


TABLE 3. Total explained variance of the scale.

\begin{tabular}{|c|c|c|c|c|c|c|}
\hline Component & Eigenvalues & $\%$ Variance & $\%$ Accumulated & Total & $\%$ Variance & $\%$ Accumulated \\
\hline 1 & 4.157 & 18.897 & 18.897 & 4.157 & 18.897 & 18.897 \\
\hline 2 & 2.506 & 11.390 & 30.287 & 2.506 & 11.390 & 30.287 \\
\hline 3 & 1.585 & 7.204 & 37.491 & 1.585 & 7.204 & 37.491 \\
\hline 4 & 1.393 & 6.334 & 43.825 & 1.393 & 6.334 & 43.825 \\
\hline 5 & 1.212 & 5.510 & 49.335 & 1.212 & 5.510 & 49.335 \\
\hline 6 & 1.111 & 5.048 & 54.489 & 1.134 & 5.154 & 54.489 \\
\hline 7 & 1.011 & 4.593 & 59.537 & 1.111 & 5.048 & 59.537 \\
\hline 8 & .955 & 4.341 & 64.131 & 1.011 & 4.593 & 64.131 \\
\hline 9 & .793 & 3.606 & 68.472 & & & \\
\hline 10 & .768 & 3.490 & 72.078 & & & \\
\hline 11 & .746 & 3.391 & 75.568 & & & \\
\hline 12 & .690 & 3.136 & 78.959 & & & \\
\hline 13 & .653 & 2.969 & 82.095 & & & \\
\hline 14 & .592 & 2.311 & 85.064 & & & \\
\hline 15 & .508 & 2.068 & 87.755 & & & \\
\hline 16 & .455 & 2.017 & 90.066 & & & \\
\hline 17 & .444 & 1.851 & 92.135 & & & \\
\hline 18 & .444 & 2.017 & 94.152 & & & \\
\hline 19 & .407 & 1.851 & 96.003 & & & \\
\hline 20 & .324 & 1.475 & 97.478 & & & \\
\hline 21 & .291 & 1.323 & 98.800 & & & \\
\hline 22 & .264 & 1.200 & 100.000 & & & \\
\hline
\end{tabular}

Extraction method: analysis of main components.

FIGURE 1. Sedimentation graph.

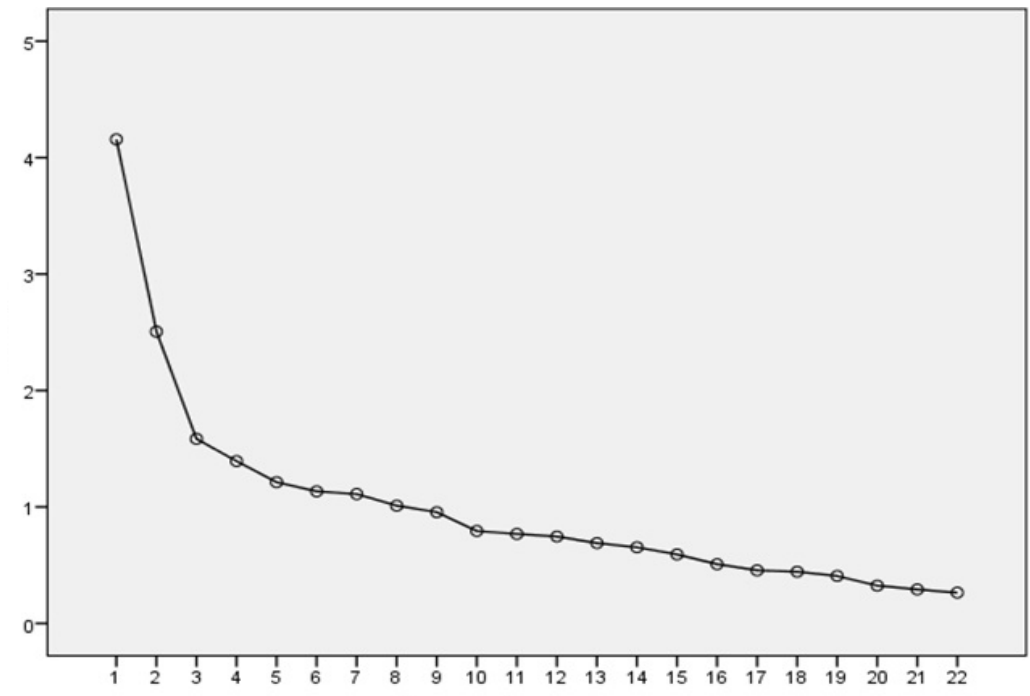


TABLE 4. Rotated Factor Matrix (items in Spanish).

\begin{tabular}{|c|c|c|c|c|}
\hline Items & 1 & 2 & 3 & 4 \\
\hline Me gustaría tener más amigos sordos. & & & .611 & \\
\hline \multicolumn{5}{|l|}{ Los niños sordos deberían ser educados en lengua de señas. } \\
\hline \multicolumn{5}{|l|}{ Las personas sordas son conductores seguros. } \\
\hline Me gustaría tener más colegas sordos. & & & .827 & \\
\hline \multicolumn{5}{|l|}{$\begin{array}{l}\text { Debe haber disponibilidad de intérpretes de lengua de señas para las personas } \\
\text { sordas en el trabajo. }\end{array}$} \\
\hline \multicolumn{5}{|l|}{ Las personas sordas no deberían ser consideradas como “discapacitadas". } \\
\hline Me gustaría ver más personas sordas en los clubes/sociedades a las que asisto. & & & .630 & \\
\hline \multicolumn{5}{|l|}{ Las personas sordas tienen su propia cultura. } \\
\hline $\begin{array}{l}\text { Las parejas de personas sordas deberían recibir consejería genética para evitar tener } \\
\text { hijos sordos. }\end{array}$ & .659 & & & \\
\hline Los niños sordos deben aprender a hablar para comunicarse con sus padres oyentes. & .716 & & & \\
\hline \multicolumn{5}{|l|}{ Los colegios para sordos y asociaciones de sordos crean guetos de sordos. } \\
\hline $\begin{array}{l}\text { Las personas sordas deben aprender a hablar más que aprender lengua de señas } \\
\text { Las personas sordas son discapacitadas. }\end{array}$ & .749 & & & .506 \\
\hline \multicolumn{5}{|l|}{ Se debería realizar más investigación para encontrar la cura a la sordera. } \\
\hline \multicolumn{5}{|l|}{ Hijos oyentes de padres sordos están en riesgo de carencia emocional. } \\
\hline Las personas sordas deberían aprender a leer labios & .664 & & & \\
\hline \multicolumn{5}{|l|}{ Las personas sordas deben recibir automáticamente ayuda en su entorno familiar. } \\
\hline \multicolumn{5}{|l|}{ A todas las personas sordas se le debería ofrecer cirugía correctiva. } \\
\hline \multicolumn{5}{|l|}{$\begin{array}{l}\text { Capacitar a más profesionales de la salud mental para trabajar con clientes sordos } \\
\text { sería una pérdida de tiempo. }\end{array}$} \\
\hline El tener un colega sordo podría causar problemas en el lugar de trabajo & & .606 & & \\
\hline Las personas sordas son fisiológicamente discapacitadas. & & & & .729 \\
\hline Debe ser difícil tener un amigo sordo. & & .576 & & \\
\hline
\end{tabular}

\section{DISCUSSION}

The exploratory factor analysis suggested the elimination of 11 items of the original ADS. The remaining 11 items were adjusted to a four-dimensional structure. The four subscales and the scale in general presented an adequate Cronbach's alpha, suggesting acceptable internal consistency (Oviedo \& Campo-Arias, 2005).

This study is the first to determine the internal consistency of the Spanish version of the ADS and to examine its factorial structure in a Chilean sample. The internal consistency of this adapted version of the ADS is similar to that obtained in its original version (Cooper et al., 2004). The authors of the EAS do not mention a defined factor structure, but in this study, through exploratory analysis, four factors were identified. In the factor analysis of the Spanish version of the Multidimensional Attitudes Scale to Persons with Disabilities (MAS), they identified four factors, unlike the three initially proposed by their authors (Stevens et al., 2013; Findler et al., 2007). When performing the exploratory factorial analysis, we found a KMO different from the one reported by Laat (2013), in which a modified version of the Chedoke-McMaster Attitudes Toward Children with Handicaps scale (CATCH) was used. 
According to the groups suggested in the four-factor model, the following names are proposed.

Dimension 1: "Oralism", since this covers items related to the oralist model. This model is characterized by focusing on the development of oral language in auditory PwD, where the Deaf person must speak and/or adapt to hearing people, ruling out the use of SL (Ladd, 2003; Lissi et al., 2012). Currently, it has been shown that the oralist model, which was used for years in Chile and different countries, has failed to achieve inclusion, because it has a spirit of "normalization" of Deaf people, instead of recognizing them as part of human diversity (Ladd, 2003; Lissi et al., 2012). This factor also includes item 1, which suggests that Deaf people should identify their risk of having Deaf children, which is in accordance with Middleton's findings (Middleton et al., 1998), where $55 \%$ of Deaf adults believe that genetic testing would do more harm than good. However, it contrasts with that reported by Brunger (2000), where hearing parents would agree with this type of genetic testing, as long as it is supported by counseling. Furthermore, as reported by Stern (2002), hearing parents have a more positive vision towards genetic testing than Deaf parents. In Chile, although there are various formal and informal initiatives of a sociocultural approach where the Deaf person is recognized as part of a linguistic minority, these are recent approaches, and thus the oralist model prevails (Ladd, 2003; Cuevas, 2013).

Dimension 2: "Awkward interaction", since it covers items related to the difficulty that could be experienced when interacting with Deaf people. This coincides with that reported in the international literature, where the interaction of Deaf people and health teams has been explored, revealing that health professionals report discomfort and difficulty in maintaining fluid communication with a Deaf patient (Ralston et al., 1996). In addition, they report difficulty understanding and being understood by the Deaf patient (Emond et al., 2015; Ralston et al., 1996; lezzoni et al., 2004), who are the most complex PwD to attend due to communication barriers (Suhani et al., 2015; Bachman et al., 2006). In particular, health professionals do not feel prepared to meet their needs Nelonaki et al., 2015; Ahmad et al., 2015). On the other hand, Deaf people feel dissatisfied with access to health services due to communication barriers and lack of awareness in health service professionals regarding the Deafness, stating that they must use a relative as interpreter, which limits their autonomy (Emond, 2015; lezzoni et al., 2004; da Silva et al., 2011).

Dimension 3: "Social acceptance" because it refers to the ability to recognize human diversity. The items are related to the approval of the social and labor participation of Deaf people. These items would be related to the implementation of the Law on Disability (Ministerio de Planificación, 2010) and the Law on Labor Inclusion (Ministerio de Desarrollo Social, 2017)in Chile. Although it corresponds to an important dimension, many people tend to perform socially correct responses in explicit questionnaires where high social acceptability is expected. This is contrasted with what was previously reported, where the results of the Implicit Association Test (IAT) do not correlate generally with the results of the implicit scales (Wilson \& Scior, 2014; Hein et al., 2011).

Dimension 4: "Vision of disability", since most people associate Deaf people as persons with disabilities, ignoring the existence of the Deaf community and the sociocultural approach with which they identify. There is extensive literature regarding the recognition of the Deaf culture and its elements, especially SL as the first language (Ladd, 2003; Lane et al., 1996). Although Chile and most of the countries currently recognize Deaf culture (De Meulder, 2015; Ministerio de Desarrollo Social, 2017), the majority of health professionals do not know about it, which is why they dominate the medical model that reduces Deaf people to a disability (Velonaki, 2015; Chaveiro, 2010).

One of the limitations of this study is the large number of professionals who refused to participate in the study, and the small sample size. Future research is proposed in order to generate an instrument that evaluates the attitudes of health professionals towards Deafness, which is adapted to the Chilean reality.

\section{CONCLUSION}

The exploratory factor analysis suggested a four-dimensional structure for ADS Chilean version. The four subscales and the scale in general presented an adequate Cronbach's alpha, suggesting an acceptable internal consistency. 


\section{REFERENCES}

Ahmad MS, Razak IA, Borromeo GL. Special Needs Dentistry: perception, attitudes and educational experience of Malaysian dental students. Eur J Dent Educ 2015;19(1):44-52.

Bachman SS, Vedrani M, Drainoni ML, Tobias C, Maisels L. Provider perceptions of their capacity to offer accessible health care for people with disabilities. Journal of Disability Policy Studies 2006;17(3), 130-136.

Beaton DE, Bombardier C, Guillemin F, Ferraz MB. Guidelines for the process of cross-cultural adaptation of self-report measures. Spine 2000;25(24):3186-91.

Brunger JW, Murray GS, 0'Riordan M, Matthews AL, Smith RJ, Robin NH. Parental attitudes toward genetic testing for pediatric deafness. Am J Hum Genet 2000;67(6):1621-5.

Campos V. Barriers deaf patients face when receiving dental treatment. J Oral Res 2016;5(4):144-145.

Chaveiro N, Barbosa MA, Porto CC, Bouttelet D, Medeiros M, Reis SB. Caring for a person that uses deaf sign language in the Perspective of the health professional. Cogitare Enfermagem 2010;15(4):639-45.

Cooper A, Rose J, Mason 0. Measuring the attitudes of human service professionals toward deafness. Am Ann Deaf 2004;148(5):385-89.

Cuevas H. El gobierno de los sordos: el dispositivo educacional. Rev cienc polít 2013;33(3):693-713.

da Silva IM, Figueirêdo EC, Rodrigues E. Deaf person's perception on health care in a midsize city: an descriptive-exploratory study. Online Brazilian Journal of Nursing 2011;10(1).

De Laat S, Freriksen E, Vervloed MP. Attitudes of children and adolescents toward persons who are deaf, blind, paralyzed or intellectually disabled. Res Dev Disabil 2013;34(2):855-63.

De Meulder M. The legal recognition of sign languages. Sign Language Studies 2015;15(4), 498-506.

Eagly AH, Chaiken S. The advantages of an inclusive definition of attitude. Social cognition 2007;25(5):582-602

Emond A, Ridd M, Sutherland H, Allsop L, Alexander A, Kyle J. Access to primary care affects the health of Deaf people. Br J Gen Pract, 2015;65(631):95-6.

Erting CJ, Johnson RC, Smith DL, Snider BD, editors. The Deaf Way: Perspectives from the International Conference on Deaf Culture. Washington DC: Gallaudet University Press; 1994.

Findler L, Vilchinsky N, Werner S. The Multidimensional Attitudes Scale Toward Persons with Disabilities (MAS): Construction and validation. RCB 2007;50(3):166-76.

Hein S, Grumm M, Fingerle M. Is contact with people with disabilities a guarantee for positive implicit and explicit attitudes?. Eur J Spec Needs Educ 2011;26(4):509-22.

Hindley P, Kitson N, editors. Mental health and deafness. London: Whurr Publishers. 2000

Humphries T, Humphries J. Deaf in the time of the cochlea. J Deaf Stud Deaf Educ 2010;16(2):153-163.

lezzoni LI, O'Day BL, Killeen M, Harker H. Communicating about health care: observations from persons who are deaf or hard of hearing. Ann Intern Med 2004;140(5):356-62.
Kiger $\mathrm{G}$. The structure of attitudes toward persons who are deaf: Emotions, values, and stereotypes. J Psychol 1997;131(5):55460.

Kuenburg A, Fellinger P, Fellinger J. Health care access among deaf people. J Deaf Stud Deaf Educ 2016;21(1):1-10.

Ladd, P. Deaf Culture: In Search of Deafhood. Clevedon, England: Multilingual Matters Ltd. 2003.

Lane HL, Hoffmeister R, Bahan BJ. A journey into the DEAFWORLD. San Diego: Dawn Sign Press;1996.

Lissi MR, Svartholm K, González M. El Enfoque Bilingüe en la Educación de Sordos: sus implicancias para la enseñanza y aprendizaje de la lengua escrita. Estudios pedagógicos 2012;38(2):299-320.

Merten JW, et al. Barriers to cancer screening for people with disabilities: A literature review. Disabil Health J 2015; 8(1):9-16.

Middleton A, Hewison J, Mueller RF. Attitudes of deaf adults toward genetic testing for hereditary deafness. Am J Hum Genet 1998;63(4)1175-80.

Ministerio de Desarrollo Social. Ley 21.015 Incentiva la inclusión de personas con discapacidad al mundo laboral. (Jun 15, 2017)

Ministerio de Desarrollo Social. Segundo Estudio Nacional de la Discapacidad. 2015

Ministerio de planificación. Ley 20422 Establece normas sobre igualdad de oportunidades e inclusión social de personas con discapacidad. (Feb 10, 2010)

Oviedo HC, Campo-Arias A. Aproximación al Uso del Coeficiente Alfa de Cronbach. Revista Colombiana de Psiquiatría 2005;34(4):572-80

Padden C, Humphries T, Inside Deaf Culture. Cambridge, MA: Harvard University Press; 2005

Palad YY, Barquia RB, Domingo HC, Flores CK, Padilla LI, Ramel JMD. Scoping review of instruments measuring attitudes toward disability. Disabil Health J 2016;9(3): 354-74.

Patka M, Keys CB, Henry DB, McDonald KE. Attitudes of Pakistani community members and staff toward people with intellectual disability. Am J Intellect Dev Disabil 2013;118(1):32-43.

Power MJ, Green AM, WHOQOL $\square$ DIS Group. The Attitudes to Disability Scale (ADS): development and psychometric properties. J Intellect Disabil Res 2010; 54(9):860-74.

Ralston E, Zazove P, Gorenflo DW. Physicians' attitudes and beliefs about deaf patients. J Am Board Fam Pract 1996;9(3):16773.

Shearer AE, Hildebrand MS, Smith RJH. In: Deafness and Hereditary Hearing Loss Overview. Adam MP, Ardinger HH, Pagon RA, Wallace SE, Bean DH, Stephens K Amemiya A, editors. Seattle (WA): University of Washington, Seattle: GeneReviews ${ }^{\circledR}$ [Internet].; 1993- 2018. pp. 159-206.

Sousa VD, Rojjanasrirat W. Translation, adaptation and validation of instruments or scales for use in cross-cultural health care research: a clear and user-friendly guideline. J Eval Clin Pract 2011;17(2):268-74.

Stern SJ, Arnos KS, Murrelle L, Welch KO, Nance WE, Pandya A. Attitudes of deaf and hard of hearing subjects towards genet- 
ic testing and prenatal diagnosis of hearing loss. J Med Genet 2002;39(6):449-53.

Stevens LF, Getachew MA, Perrin PB, Rivera D, Plaza 0, Leonor $\mathrm{S}$, Arango-Lasprilla JC. Factor analysis of the Spanish Multidimensional Attitudes Scale Toward Persons with Disabilities. Rehabil Psychol 2013;58(4):396.

Stevens LF, Getachew MA, Perrin PB, Rivera D, Plaza 0, Leonor $\mathrm{S}$, Arango-Lasprilla JC. Factor analysis of the Spanish Multidimensional Attitudes Scale Toward Persons with Disabilities. Rehabil Psychol 2013;58(4):396-404.

Suhani RD, Suhani MF, Muntean A, Mesaros M, Badea ME. Ethical dilemmas concerning the dental treatment of patients with hearing impairment. Revista Romana de Bioetica 2015;13(3):14960.

Velonaki VS, Kampouroglou G, Velonaki M, Dimakopoulou K, Sourtzi P, Kalokerinou A. Nurses' knowledge, attitudes and behavior toward Deaf patients. Disabil Health J 2015;8(1):109-17.

Wilson MC, Scior K. Attitudes towards individuals with disabilities as measured by the Implicit Association Test: A literature review. Res Dev Disabil 2014;35(2):294-321.

World Health Organization. Deafness and hearing loss (Fact sheet $\mathrm{N}^{\circ} 300$ ). Geneva: World Health Organization; 2015 